\title{
EFEKTIFITAS KOMPRES HANGAT DAUN KELOR TERHADAP NYERI ASAM URAT PADA LANSIA DI DESA KENTENG,NOGOSARI, BOYOLALI
}

\author{
The Effectiveness of Warm Compress of Moringa Leaves Against Uric Acid Pain \\ in the Elderly in Kenteng, Nogosari, Boyolali.
}

Aris Widiyanto ${ }^{1}$, Krisnanda Aditya Pradana ${ }^{2}$,Faisal Hidayatullah ${ }^{3}$, Joko Tri Atmojo $^{1}$, Ndaru Syukma Putra ${ }^{3}$, Asruria Sani Fajriah ${ }^{3}$

${ }^{1}$ STIKES Mamba'ul 'Ulum Surakarta

${ }^{2}$ RSUD dr. Sayidiman Magetan

${ }^{3}$ IIK Strada Indonesia

(Widiyanto.aris99@gmail.com)

\begin{abstract}
ABSTRAK
Latar Belakang : Penyakit asam urat (arthritis gout) adalah penyakit yang sering ditemukan di seluruh dunia yang ditandai dengan nyeri berulang-ulang disebabkan adanya endapan kristal monosodium urat yang terkumpul didalam sendi sebagai akibat tingginya kadar asam urat darah. Upaya mengurangi nyeri pada gout dilakukan tindakan farmakologis diberikan obat anti nyeri sedangkan secara non farmakologi manajemen nyeri dengan pemberian relaksasi analgesik dan relaksasi intervensi perilaku kognitif salah satunya yaitu kompres hangat daun kelor.

Tujuan : Penelitian ini bertujuan untuk mengetahui efektifitas kompres hangat daun kelor terhadap nyeri asam urat pada lansia di desa Kenteng, Nogosari, Boyolali.

Metode : Penelitian ini merupakan penelitian kuantitatif, metode penelitian menggunakan Quasy Experiment dengan pendekatan one-group pre-post test design. Teknik sampel yang digunakan adalah Purposive sampling sejumlah 40 responden. Pada penelitian ini menggunakan alat pengumpul data berupa kuesioner, jenis kuesioner dalam penelitian ini adalah kuesioner dengan skala nyeri NRS. Analisa data dalam penelitian ini menggunakan uji Wilcoxon.

Hasil : Karakteristik responden mayoritas laki-laki yaitu 21 orang $(52,5 \%)$, lama menderita asam urat mayoritas lebih dari 1 tahun yaitu 23 orang $(57,5 \%)$ dan ratarata usia 67 tahun. Skala nyeri sebelum intervensi rata-rata 5 dan sesudah intervensi rata-rata adalah 1. Hasil uji wilcoxon didapatkan nilai $p$ value $0,000<$ 0,05 , yang berarti kompres hangat daun kelor efektif menurunkan nyeri asam urat pada lansia di Desa Kenteng, Nogosari, Boyolali

Simpulan: Kompres hangat daun kelor efektif menurunkan nyeri asam urat pada lansia di Desa Kenteng, Nogosari, Boyolali
\end{abstract}

Kata kunci: Kompres Hangat Daun Kelor, Nyeri, Asam Urat 


\begin{abstract}
Background : Gout disease (arthritis gout) is a disease that is often found around the world which is characterized by repeated pain caused by deposits of monosodium urate crystals that collect in the joints as a result of high blood uric acid levels. Efforts to reduce pain in gout are carried out by pharmacological action given anti-pain drugs while non-pharmacologically pain management by providing analgesic relaxation and relaxation of cognitive behavioral interventions, one of which is warm compresses of Moringa leaves.

Purpose : This study aims to determine the effectiveness of warm compresses of Moringa leaves on gout pain in the elderly in Kenteng village, Nogosari, Boyolali.

Methods : This research is a quantitative study, the research method uses Quasy Experiment with aapproach one-group pre-post test design. The sample technique used was purposive sampling of 40 respondents. In this study, using a data collection tool in the form of a questionnaire, the type of questionnaire in this study was a questionnaire with thepain scale NRS. Analysis of the data in this study using thetest Wilcoxon.
\end{abstract}

Results : Characteristics of the sex of the respondents, namely the majority were men, namely 21 people (52.5\%), long suffering from gout in the patients, the majority of pain was more than 1 year, namely 23 people (57.5\%) get lowest age was 60 years, oldest age 77 years with an average age of 67 years. The pain scale before getting the mininal value was 4, the maximum value was 6 and the average was 5 and the pain scale after the mininal value was 1, the maximum value was 3 and the average was 1.Thetest results Wilcoxon pain scalein acid sufferers uric before and after giving warm compresses of Moringa leaves with ap value of $0.000<0.05$, which means that warm compresses of Moringa leaves are effective in reducing uric acid pain in the elderly in Kenteng Village, Nogosari, Boyolali.

Conclusion: Warm compresses of Moringa leaves are effective in reducing gout pain in the elderly in Kenteng Village, Nogosari, Boyolali

Keywords: Warm Compress of Moringa Leaves, Pain, Gout

\title{
PENDAHULUAN
}

Penyakit asam urat (arthritis gout) adalah penyakit yang sering ditemukan dan tersebar di seluruh dunia. Gangguan metabolisme nyang mendasarkan gout adalah hiperurisemia yang didefinisikan sebagai peninggian kadar asam urat lebih dari 7,0 ml/dl dan 6,0 mg/dl (Sudoyo, 2009). Pada orang dewasa di Amerika Serikat penyakit gout mengalami peningkatan dan mempengaruhi 8.3 juta (4\%) orang Amerika. Prevalensi hiperurisemia juga meningkat dan mempengaruhi 43.300.000 (21\%) orang dewasa di Amerika Serikat (Zhu dkk, 2011 dalam Sun, 2014).

Menurut World Health Organization (WHO) tahun 2013, sebesar $81 \%$ penderita asam urat di Indonesia hanya $24 \%$ yang pergi ke dokter, sedangkan 71 
$\%$ cenderung langsung mengkonsumsi obat-obatan pereda nyeri yang dijual bebas (WHO, 2015). Prevalensi penyakit asam urat di Indonesia terjadi pada usia di bawah 34 tahun sebesar $32 \%$ dan di atas 34 tahun sebesar $68 \%$ (Jaliana, Suhadi \& La Ode, 2018). Hasil riset kesehatan dasar (Riskesdas) tahun 2018 menunjukkan bahwa penyakit sendi di Indonesia berdasarkan diagnosis dokter sebesar 7,3\% sedangkan berdasarkan daerah diagnosis dokter tertinggi di Provinsi Aceh sebesar $13.3 \%$ dan berdasarkan diagnosis dan gejala tertinggi yaitu di Nusa Tenggara Timur sebesar $31.1 \%$. Prevalensi penyakit sendi di Jawa Tengah pada tahun 2018 berdasarkan diagnosis dokter mengalami penurunan dibanding tahun 2013 dari 11,9\% menjadi 7,3\% (Riskesdas, 2018).

Gout Arthritis merupakan penyakit yang ditandai dengan nyeri yang terjadi berulang-ulang yang disebabkan adanya endapan kristal monosodium urat yang terkumpul didalam sendi sebagai akibat dari tingginya kadar asam urat didalam darah (Anjarwati dalam Winarsih \& Sani, 2010). Asosiasi Internanasional untuk Penelitian Nyeri (International Association forthe Study of Pain, IASP) mendefinisikan nyeri sebagai suatu sensori subjektif dan pengalaman emosional yang tidak menyenangkan berkaitan dengan kerusakan jaringan yang aktual atau potensial atau yang dirasakan dalam kejadian-kejadian dimana terjadi kerusakan (Winarsih \& Sani, 2010). Nyeri adalah sensasi yang tidak menyenangkan dan sangat individual yang tidak dapat dibagi kepada orang lain. Nyeri dapat memenuhi seluruh pikiran seseorang, mengatur aktivitasnya, dan mengubah kehidupan orang tersebut (Berman \& Kozier 2009). Stimulus nyeri dapat berupa stimulus yang bersifat fisik dan atau mental, sedangkan kerusakan dapat terjadi pada jaringan aktual atau pada fungsi ego individu (Potter \& Perry, 2009)..

Asam urat penyakit dengan gejala yang sangat khas, yaitu radang sendi akut dan timbul sangat cepat dalam waktu singkat. Pasien tidur tanpa ada gejala apapun, kemudian bangun tidur terasa sakit yang hebat dan tidak dapat berjalan. Keluhan monoartikuler berupa nyeri, bengkak, merah dan hangat, disertai keluhan sistemik berupa demam, menggigil dan merasa lelah, disertai leukositosis dan peningkatan laju endap darah (Rofi, Nyoman \& Deddy, 2011).

Upaya untuk mengurangi nyeri pada klien gout dapat dilakukan dengan tindakan farmakologis dan nonfarmakologis. Secara farmakologi maka pasien diberikan obat-obatan anti nyeri atau penghilang rasa sakit. Sedangkan secara non farmakologi manajemen nyeri meliputi pemberian relaksasi analgesik dan relaksasi nonfarmakologi berupa intervensi perilaku kognitif seperti teknik relaksasi, relaksasi musik, imaginary dan biofeedback (Smeltzer et al, 2008).

Penanganan nyeri asam urat secara non farmakologi dapat diberikan kompres hangat (Aisyah, 2017). Menurut Indah, Nurhayati, Setiyajati (2013) penerapan kompres hangat yang telah sering dilakukan dapat dikolaborasi dengan beberapa tanaman herbal. Tanaman herbal seperti jahe, serai selain itu tanaman herbal daun kelor. Kelor (Moringa oleifera) adalah sejenis tumbuhan dari suku Moringaceae (Raji dan Njidda, 2014). Kelor memiliki kandungan senyawa yang penting bagi tubuh, daun kelor juga mengandung zat fitokimia seperti tannin, steroid, triterpenoid, flavonoid, saponin, antrakuinon dan alkaloid. Senyawa 
tersebut mempunyai kemampuan sebagai obat antibiotik, antiiflamasi, detoksifikasi dan antibakteri (Mardiana, 2013).

Khususnya senyawa flavonoid dapat bekerja menghambat xanthine oxidase. Xanthine oxidase adalah enzim yang bekerja mengoksidasi hipoxanthine menjadi xanthine dan selanjutnya membentuk asam urat di dalam tubuh (Yunahara \& Rifaldi, 2016). Hasil penelitian Sulistyawati \& Pratiwi (2016) mengatakan esktrak daun kelor memiliki kandungan analgesik dan antiinflamasi. Didukung hasil penelitian Anshory dkk (2018) mengatakan esktrak daun kelor memiliki kandungan analgesik lebih baik dibandingkan meloksikam. Kandungan flavonoid pada daun kelor berkhasiat sebagai analgetik yang mekanisme kerjanya menghambat kerja enzim siklooksigenase. Penghambatan enzim siklooksigenase akan mengurangi produksi prostaglandin sehingga mengurangi rasa nyeri. Flavonoid juga menghambat degranulasi neutrofil sehingga akan menghambat pengeluaran sitokin, radikal bebas, serta enzim yang berperan dalam peradangan (Syamsul, dkk., 2016).

Berdasarkan latar belakang di atas, penulis tertarik untuk melakukan penelitian tentang "efektifitas kompres hangat daun kelor terhadap nyeri asam urat pada lansia di desa Kenteng, Nogosari, Boyolali," sehingga dapat meningkatkan pengetahuan khususnya bagi lansia tentang penanganan nyeri asam urat.

\section{METODE PENELITIAN}

Penelitian ini merupakan penelitian dengan quasi exsperiment design. Populasi penelitian ini adalah semua penderita asam urat di desa Kenteng, Nogosari, Boyolali. Subyek penelitian ini adalah seluruh lansia yang menderita asam urat di desa Kenteng, Nogosari, Boyolali yang berjumlah 40 orang dilakukan pada bulan Juni 2020.

Penelitian ini menggunakan kuesioner dengan skala nyeri Numeric Rating Scale (NRS) yang dibagikan langsung kepada lansia. Metode pengumpulan data menggunakan purposive sampling. Intervensi yang diberikan pada lansia berupa kompres hangat daun kelor yang diberikan 1 kali sehari pada pagi hari selama 20 menit yang diberikan secara 3 hari berturut-turut. Analisa data dalam penelitian ini menggunakan uji wilcoxon. Penelitian ini sudah melewati ethical clearance yang dilaksanakan di RSUD dr. Moewardi. 


\section{HASIL DAN PEMBAHASAN}

\section{Hasil}

\section{A. Analisa Univariat}

Tabel 1 Distribusi Frekwensi Karakteristik Responden Berdasarkan Usia, Jenis Kelamin Dan Lama Menderita Asam Urat

\begin{tabular}{|c|c|c|c|c|c|}
\hline \multicolumn{3}{|c|}{ Karakteristik } & \multicolumn{2}{|r|}{ Frekwensi (f) } & Prosentase $(\%)$ \\
\hline \multicolumn{6}{|c|}{ Jenis Kelamin } \\
\hline Laki-Laki & & & & 21 & 52,5 \\
\hline Perempuan & & & & 19 & 47,5 \\
\hline Total & & & & 40 & 100 \\
\hline \multicolumn{6}{|c|}{ Lama Menderita Asam Urat } \\
\hline$<1$ Tahun & & & & 17 & 42,5 \\
\hline >1Tahun & & & & 23 & 57,5 \\
\hline Total & & & & 40 & 100 \\
\hline \multirow[t]{2}{*}{ Usia } & Min & Max & Mean & SD & Median \\
\hline & 60 & 77 & 67,05 & 4,568 & 67 \\
\hline
\end{tabular}

Berdasarkan Tabel 1. menunjukkan karakteristik jenis kelamin responden, mayoritas adalah laki-laki yaitu 21 orang $(52,5 \%)$, lama menderita asam urat pada pasien didapatkan mayoritas nyeri lebih dari 1 tahun yaitu 23 orang $(57,5 \%)$ dan pada karakteristik usia responden di dapatkan usia terendah adalah 60 tahun, usia tertua 77 tahun dengan rata-rata usia 67 tahun.

Tabel 2 Distribusi Frekuensi Skala Nyeri Sebelum Dan Sesudah Kompres Hangat Daun Kelor Terhadap Nyeri Asam Urat Pada Lansia

\begin{tabular}{cccccc}
\hline Karakteristik & \multicolumn{5}{c}{ Frekwensi } \\
\hline Skala Nyeri Sebelum & Min & Max & Mean & SD & Median \\
& 4 & 6 & 5,02 &, 768 & 5 \\
Skala Nyeri Sesudah & Min & Max & Mean & SD & Median \\
& 1 & 3 & 1,90 &, 709 & 2 \\
\hline
\end{tabular}

Tabel 2 diatas menunjukkan bahwa skala nyeri sebelum di dapatkan nilai mininal adalah 4, nilai maksimal adalah 6 dan rata-rata adalah 5 serta skala nyeri sesudah di dapatkan nilai mininal adalah 1, nilai maksimal adalah 3 dan rata-rata adalah 1 . 


\section{B. Analisa Univariat}

Tabel 3 Analisa Uji Wilcoxon Efektifitas Kompres Hangat Daun Kelor Terhadap Nyeri Asam Urat Pada Lansia

\begin{tabular}{cccc}
\hline Variabel & Selisih & $\mathbf{Z}$ & P-value \\
\hline Nyeri Sebelum - Sesudah & 3,12 & $-5,675^{\mathrm{a}}$ & 0,000
\end{tabular}

Tabel 3 diatas menunjukkan bahwa bahwa hasil uji wilcoxon skala nyeri pada penderita asam urat sebelum dan sesudah pemberian kompres hangat daun kelor dengan nilai $p$ value $0,000<0,05$, yang berarti kompres hangat daun kelor efektif menurunkan nyeri asam urat pada lansia di Desa Kenteng, Nogosari, Boyolali.

\section{Pembahasan}

Berdasarkan Tabel 1. dapat dilihat bahwa pada jenis kelamin responden menunjukan bahwa jenis kelamin mayoritas responden adalah laki-laki sebanyak 21 responden $(52,5 \%)$ sejalan dengan penelitian Ode (2012), pada umumnya para pria lebih banyak terserang asam urat dan kadar asam urat kaum pria cenderung lebih meningkat sejalan dengan perkembangan usia. Laki-laki tidak memiliki hormon esterogen sedangkan pada perempuan memiliki hormon estrogen yang berfungsi sebagi uricosuric agent yaitu suatu bahan kimia yang berfungsi membantu ekskresi asam urat lewat ginjal (Setyoningsih, 2014). Asupan purin pada laki-laki lebih tinggi dibanding perempuan, laki-laki mengkonsumsi puri dalam kategori tinggi yaitu > 6205mg/hari sehingga menyebabkan asam urat (Rini, 2017). Untuk lama mederita asam urat responden menunjukan bahwa lama menderita asam urat diketahui bahwa mayoritas responden menderita asam urat adalah lebih dari 1 tahun sebanyak 23 responden (57,5\%). Pasien yang pernah mengalami nyeri sebelumnya memiliki intensitas nyeri yang lebih rendah dibandingkan yang tidak pernah mengalami nyeri sebelumnya (Redho dkk, 2019). Pengalaman masa lalu terpapar nyeri dapat mengurangi kecemasan dan membuat pasien lebih toleran terhadap rasa sakit dibandingkan yangmemiliki sedikit pengalaman dengan nyeri (Smetlzer \& Bare, 2010) Serta untuk usia responden diketahui bahwa usia rata-rata 67 tahun, median 67 tahun dengan usia tertua 77 tahun dan termuda 60 tahun. Menurut Andry. Dkk (2009) bahwa salah satu penyebab dari penyakit asam urat adalah usia. Prevalensi kejadian asam urat lebih banyak terjadi antara umur 30-50 tahun. Menurut teori yang dikemukakan Ode (2012), usia dapat dijadikan faktor resiko terjadinya gout karena ketika seseorang bertambah tua maka akan terjadi perubahan (penurunan) pada proses metabolisme dalam tubuh dan gout merupakan penyakit yang diakibatkan oleh gangguan metabolisme asam urat dalam tubuh.

Tabel 2. Menunjukkan menunjukkan bahwa skala nyeri asam urat sebelum pemberian kompres hangat daun kelor didapatkan bahwa skala nyeri sebelum di dapatkan nilai mininal adalah 4, nilai maksimal adalah 6 dan rata-rata adalah 5 , hasil penelitian Rista dkk (2014) bahwa sebagian besar responden mengalami 
nyeri dalam kategori sedang dengan jumlah 17 (48,6\%). Pengukuran skala nyeri penderita asam urat dalam penelitian ini, menggunakan kriteria tidak nyeri $(0)$, nyeri ringan (1-3), nyeri sedang (4-6). Hal ini diasumsikan bahwa nyeri ringan dan nyeri sedang masih dapat ditangani dengan terapi komplementer dan dapat di lakukan sendiri oleh penderita. Dapat diartikan nyeri sedang merupakan nyeri yang timbul dengan intensitas yang sedang. Pada nyeri sedang secara obyektif pasien mendesis, menyeringai, dapat menunjukkan lokasi nyeri dengan baik. Serangan gout muncul pada sendi akibat reaksi inflamasi karena adanya sel-sel darah putih yang menganggap kristal ini adalah benda asing. Bagian sendi yang terkena akan terasa sakit karena adanya kristal dan kulit yang menjadi sangat sensitive dan akan menimbulkan nyeri (Damayanti,2012), serta skala nyeri sesudah di dapatkan nilai mininal adalah 1, nilai maksimal adalah 3 dan rata-rata adalah 1. Penanganan yang sering dilakukan untuk mengurangi nyeri asam urat umumnya dilakukan dengan memakai obat, yaitu kelompok salisilat dan kelompok obat anti inflamasi nonsteroid. Obat-obat non opioid kerap kali untuk penanganan nyeri, khususnya pada tahap dalam program terapi. Salah satu efek yang serius dari obat anti inflamasi nonsteroid adalah pendarahan saluran cerna. Risiko tersebut akan semakin besar dengan semakin tingginya dosis, pemakaian campuran, dan tingginya usia penderita (Smeltzer \& Bare, 2008). Penanganan non farmakologis kini sudah mulai dilirik masyarakat banyak karena sangat mudah untuk dipraktekkan dan tidak mengeluarkan biaya yang mahal. Penanganan non farmakologis juga tidak memiliki efek samping yang berbahaya seperti penanganan farmakologis (Monks \& Knoers, 2005). Salah satu penanganan non farmakologis dalam penyembuhan penyakit asam urat yaitu dengan terapi komplementer. Salah satu penanganan non farmakologis dalam penyembuhan penyakit asam uratyaitu dengan terapi komplementer. Terapi komplementer bersifat terapi pengobatan alamiah diantaranya adalah dengan terapi herbal, terapi nutrisi, akupuntur dan akupresur, relaksasi progresif, meditasi, homeopati, aromaterapi, terapi bach flower remedy, dan refleksiologi, terapi es dan panas, teknik relaksasi, distraksi, biofeedback, hipnosis diri (Nuraini, 2011). Salah satu terapi herbal dapat menggunakan daun kelor. Daun kelor bisa untuk mengobati rematik karena memiliki kandungan seperti flavanoid, alkaloid, steroid, tanin, saponin, terpenoid (Wijaya, 2017). Flavonoid menghambat degranulasi neutrofil sehingga akan menghambat pengeluaran sitokin, radikal bebas, serta enzim yang berperan dalam peradangan (Mohan dkk, 2012). Flavonoid ini berfungsi sebagai analgesik yang menghambat kerja enzim siklooksigenase dan lipoksigenase sehingga dapat mengganggu sintesis prostaglandin dan mengurangi rasa nyeri (Suryanto, 2012). Menurut penelitian Hilyani (2017) mengatakan ekstrak air daun kelor dapat sebagai analgesik. Penggunaan terapi herbal dapat dilakukan bersamaan dengan kompres hangat. Mengompres berarti memberikan rasa hangat pada klien dengan menggunakan cairan atau alat yang menimbulkan rasa hangat pada bagian tubuh tertentu yang memerlukannya (Fanada, 2012)

Tabel 3 menunjukkan bahwa bahwa hasil uji wilcoxon skala nyeri pada penderita asam urat sebelum dan sesudah pemberian kompres hangat daun kelor 
dengan nilai $p$ value $0,000<0,05$. Hasil penelitian Khongrum \& Wattanathorn (2012) mengatakan ekstrak daun kelor dapat digunakan sebagai terapi adjuvant untuk managemen nyeri neuropatik akibat cidera kontriksi kronis. Hasil Ramadhani \& Sumiwi (2016) mengatakan senyawa pada tanaman yang diduga memberikan aktivitas antiinflamasi tersebut adalah senyawa golongan flavonoid. Hasil penelitian Ramadhan (2017) juga membuktikan bahwa ekstrak air daun kelor mampu menghambat repon terhadap nyeri dan memiliki efek analgesik dan antiinflamasi dan di ketahui ampuh mengusir penyakit sendi Kemampuan daun kelor dalam mengatasi rasa nyeri dikarenakan adanya kandungan flavonoid yang mekanisme kerjanya adalah menghambat kerja enzim siklo-oksigenase sehingga pembentukan prostaglandin terhambat, dengan demikian akan mengurangi rasa nyeri (Mohan dkk, 2012). Enzim siklo-oksigenase ini dapat mengurangi peradangan dengan mengurangi proses reproduksi mediator peradangan (Price, 2009). Kompres hangat daun kelor, pada air yang digunakan untuk terapi memiliki suhu 37-39C. Suhu tersebut dapat mengobati gejala kurang tidur dan infeksi, meningkatkan kelenturan otot jaringan ikat, kelenturan pada otot, mestabilkan kerja jantung dan alian darah, memberikan pengaruh pada sistem pembuluh darah sehinggan aliran darah menjadi lancar (Setiyoadi \& Kushariyadi, 2011). Menurut Pratiwi (2017), ketika pasien mengalami nyeri dimana pada saat kompres diletakkan ditempat yang nyeri maka rasa panas tersebut akan berpindah ketubuh atau kulit, sehinga terjadilah proses konduksi yang terjadi pada tubuh sehingga menyebabkan vasodilatasi pembuluh darah dan menurunkan otot yang tegang agar otot menjadi relaksasi dan rasa nyeri akan berkurang

\section{SIMPULAN DAN SARAN}

\section{Simpulan}

Karakteristik jenis kelamin responden, mayoritas adalah laki-laki yaitu 21 orang $(52,5 \%)$, lama menderita asam urat pada pasien didapatkan mayoritas nyeri lebih dari 1 tahun yaitu 23 orang $(57,5 \%)$ dan pada karakteristik usia responden di dapatkan usia terendah adalah 60 tahun, usia tertua 77 tahun dengan rata-rata usia 67 tahun. Skala nyeri sebelum di dapatkan nilai mininal adalah 4, nilai maksimal adalah 6 dan rata-rata adalah 5 serta skala nyeri sesudah di dapatkan nilai mininal adalah 1, nilai maksimal adalah 3 dan rata-rata adalah 1 . Hasil uji wilcoxon skala nyeri pada penderita asam urat sebelum dan sesudah pemberian kompres hangat daun kelor dengan nilai $p$ value $0,000<0,05$, yang berarti yang berarti kompres hangat daun kelor efektif menurunkan nyeri asam urat pada lansia di Desa Kenteng, Nogosari, Boyolali.

\section{Saran}

Diharapkan bagi masyarakat dapat melakukan terapi komplementer kompres hangat daun kelor untuk menurunkan nyeri asam urat pada lansia agar tidak ketergantungan dengan terapi farmakologi yang memiliki efek samping untuk tubuh. Diharapkan bagi peneliti selanjutnya bisa dijadikan referensi atau 
acuan tambahan apabila di adakan penelitian lebih lanjut khususnya bagi yang ingin memeberikan kompres hangat daun kelor pada penyakit lain..

\section{DAFTAR PUSTAKA}

Aisyah, Siti (2017). Manajemen Nyeri Pada Lansia Dengan Pendekatan Non Farmakologi. Fakultas Ilmu Kesehatan Universitas Muhammadiyah Surabaya. Jurnal Keperawatan Muhammadiyah, 2 (1):1-9

Andry, Saryono, dan Arif Setyo Upoyo, (2009), Analisis Faktor - Faktor Yang Mempengaruhi Kadar Asam Urat Pada Pekerja Kantor Di Desa Karang Turi, Kecamatan Bumiayu, Kabupaten Brebes, Jurnal Keperawatan Soedirman (The Soedirman Journal of Nursing), 4(1):1-7

Berman, Snyder, Kozier, Erb, (2009).Buku Ajar Keperawatan Klinis Kozier \& Erb. Edisi 5.Jakarta: EGC

Damayanti D.(2012).Panduan Lengkap Mencegah dan Mengobati Asam Urat.Yogyakarta;Penerbit

Fanada, Mery. (2012). Pengaruh Kompres Hangat Dalam Menurunkan Skala Nyeri Pada lansia Yang Mengalami Nyeri Rematik Di Panti Sosial Tresna Werdha. Badan Diklat Sumatera Selatan. Palembang.

Indah, Nurhayati \& Setiajati (2013). Terapi Kompres Jahe dan massage pada osteoarthitis di panti wreda ST. Theresia Darma Bhakti Kasih Surakarta.

Kushariyadi, Setyoadi. (2011). Terapi Modalitas Keperawatan Pada Klien Psikogeriatrik. Penerbit: Salemba Medika. Jakarta

Mardiana, Lina. 2013. Daun Ajaib Tumpas Penyakit. Jakarta : Penebar Swadaya

Mohan N., Guleca VS.,Aurangbadkar V.M., Balaraman R., Austin A. \& Thirugananasampatan S. (2012). Analgesic and antyinflamatory activity of a polyherbal formulation (PHF-AROGH). Oriental pharmacy and experimental medicine. 9 (3). 232-237

Monks Dan Knoers (2005). Terapi Asam Urat. Jakarta: PT.

Nuraini.(2011) . Aneka manfaat buah dan sayuran.Yogyakarta:Andi S

Ode, Sharif. (2012). Konsep Dasar Keperawatan. Yogyakarta : Nuha Medika

Potter, P. A., \& Perry, A. G. (2009). Fundamentals of nursing, fundamental keperawatan. Edisi 7, Buku 1 dan 2. Jakarta: EGC.

Pratiwi. L. (2017). Pengaruh Jahe terhadap Nyeri saat Menstruasi Bagian Parasitologi, Fakultas Kedokteran, Universitas Lampung Fakultas Kedokteran, Universitas Lampung.

Price Sylvia A, Wilson Lorraine M. (2009).Patofisiologi: Konsep Klinis ProsesProses Penyakit. Jakarta: EGC;

Raji, A.Y. \& Njidda, A.A. (2014). Gonadal and extragonodal sperm reserves of the Red Sokoto goats fed Moringa oleifera supplemented diets. Inter. J. Agri Biosci. 3(2):61-64

Ramadhani N, Sumiwi S.(2016). Aktivitas Antiinflamasi Berbagai Tanaman Diduga Berasal dari Flavonoid. Farmaka Suplemen.14(2):111-123 
Redho, Ahmad, dkk. 2019. Pengaruh self healing terhadap penurunan sskala nyeri pasien post operasi. Jurnal Keperawatan dan Kebidanan . Vol 1. No 1

Rini.(2017). Hubungan Jenis Kelamin Dan Asupan Purin Dengan Kadar Asam Urat Pada Lansia Di Posyandu Peduli Insani Mendungan Desa Pabelan Kecamatan Kartasura Kabupaten Sukoharjo. http://eprints.ums.ac.id/49781/24/NASKAH\%20PUBLIKASI.pdf. Diakses 15 April 2020

Riset Kesehatan Dasar (Riskesdas). (2018). Badan penelitian dan pengembangan kesehatan kementerian RI tahun 2018.Diakses: 12 Desember 2020, dari http://www.depkes.go.id/resources/download/general/Hasil\%20Riskesdas\% 202013.pdf

Rista A, Dwi R, Joko S.(2014). Pengaruh rebusan daun sirsak untuk menurunkan nyeri gout Atrhitispada lansia. Skripsi. Stikes widya husada semarang

Rofi R, Nyoman K, Deddy N. (2011). Hubungan Dukungan Sosial Terhadap Derajat Nyeri pada Penderita Artritis Gout Fase Akut. Fakultas Kedokteran, Universitas Gadjah Mada, Yogyakarta

Setyoningsih,R.(2014).Faktor-Faktor yang Berhubungan dengan Kejadian Hiperurisemia pada Pasien Dr.Kariadi Semarang. Skripsi. Semarang: Fakultas Kedokteran UNDIP

Smeltzer \& Bare, (2010), Buku Ajar Keperawatan Medikal Bedah,. EGC, Jakarta

Smeltzer et al, (2008), Buku Ajar Keperawatan Medikal Bedah, edisi 8 vol 3, EGC, Jakarta

Sudoyo A,W. 2009. Buku Ajar Ilmu Penyakit Dalam, jilid II, edisi V.Jakarta: Interna Publishing. Dinas kesehatan Provinsi Jawa Tengah. 2015. Profil Kesehatan Provinsi Jawa tengah Tahun 2015. Jawa Tengah:Dinkes Provinsi Jawa Tengah

Sulistyawati dan Pratiwi P.Y. 2015. Pengaruh Pemberian Etanol Daun Kelor (Moringa Oleifera L) Terhadap Aktivitas Analgesik dan Antiinflamasi Melalui Ekspresi Enzim Siklooksigenase. Akademi Analisis Farmasi Makanan dan Minuman. AL Islam Yogyakarta

Sun, H. (2014). Development Of Gout Patient Education Pamphlet In Chinese To Improve Population Health. California State University

Suryanto, E. (2012). Fotokimia Antioksida. Penerbit PMN, Surabaya.

Syamsul, E.S., Lestari, D. \& Heldyana S. (2016). Potensi ektrak air daun pacar cina (aglayna odorata) sebagai biolarvasida terhadap larva. Aedes aegepti. Prosiding Seminar Kimia.

WHO. (2015). A Global Brief On Uric Acid. Geneva.

Wijaya (2009). Kajian Standar teknis standart nasional indonesia. Biskuit SNI 01 2973-1992 Balai Besar Industri Argo, Kementrian Perindustrian.

Winarsih, \& Sani, A. T. (2010). Perbedaan Efektifitas Kompres Hangat Dan Kompres Dingin Terhadap Skala Nyeri Pada Klien Gout Di Wilayah Kerja Puskesmas Batang III Kabupaten Batang. Skripsi. Program Studi S1 Keperawatan Sekolah Tinggi Ilmu KesehatanMuhammadiyah Pekajangan 
Yunahara Farida, Rifaldi Agustian Firmansyah, (2016). Aktivitas Penghambatan Xanthine Oxidase Ekstrak Etanol Dan Air Dari Herba Suruhan (Peperomia pellucida L.). Fakultas Farmasi Universitas Pancasila, Jakarta 